\title{
Global GI malignancies: a population health management perspective
}

The increasing issues of globalization and caring for our populations have created a unified effort of all healthcare stakeholders worldwide (1). Population health has emerged to integrate public health, health policy, quality and safety, as well as chronic care management under one roof (2). Although the concept of population health has been around for generations, a measurable definition of "population-level health outcomes" with the health factors and policy/interventions that influence it was not reported until Kindig and Stoddart in 2003 (3). A simplified grouping of health factors into four categories consisting of health behaviors, clinical care, social \& economic factors, and physical environment serves as an entry point for identification of gaps in the health of a population or subpopulation (4). Importantly, social determinants of health (SDoH) contribute to approximately eighty percent of population health issues. The World Health Organization describes SDoH as "the conditions which people are born, grow, live, and age (1)." The question for all countries worldwide becomes "how can we achieve the goal of improving health care given our available resources?" The Quadruple Aim proposed by the Institute of Healthcare Improvement, in addition to improving outcomes, emphasized improving the patient and provide experience while reducing per capita cost. The adoption of global population health management (GPHM) strategies is described as a system of coordinated healthcare interventions. GPHM focuses on identifying a similar group's risk factors, determining strategies to improve the health of the group, identifying preventive care intervention and utilizing aggregated data to support the clinical decision-making process $(5,6)$.

The combination of increasing global burden of gastrointestinal (GI) malignancies and rising age portends a future health crisis (7). This focus series of global GI malignancies from a population health management perspective is intended to provide a broad overview of relevant topics. Specifically, the importance of the GI microbiome, oral health, and the brain-gut axis as drivers of health is introduced. Value-base population health management and the chronic care model provide interventions across continuum of care coordination. Evidence-based strategies to eliminate GI vaccination-preventable disease is discussed. Finally, organ-specific malignancies and their socioeconomic determinants impacting geographic regions worldwide are reviewed.

\section{Acknowledgments}

Funding: None.

\section{Footnote}

Provenance and Peer Review: This article was commissioned by the editorial office, Fournal of Gastrointestinal Oncology for the series "Global GI Malignancies". The article did not undergo external peer review.

Conflicts of Interest: Both authors have completed the ICMJE uniform disclosure form (available at http://dx.doi.org/10.21037/ jgo-2019-gi-12). The series "Global GI Malignancies" was commissioned by the editorial office without any funding or sponsorship. JFG and QDC served as the unpaid Guest Editors of the series. JFG serves as an unpaid editorial board member of Journal of Gastrointestinal Oncology from Jan 2019 to Dec 2020.

Ethical Statement: The authors are accountable for all aspects of the work in ensuring that questions related to the accuracy or integrity of any part of the work are appropriately investigated and resolved.

Open Access Statement: This is an Open Access article distributed in accordance with the Creative Commons AttributionNonCommercial-NoDerivs 4.0 International License (CC BY-NC-ND 4.0), which permits the non-commercial replication and distribution of the article with the strict proviso that no changes or edits are made and the original work is properly cited 
(including links to both the formal publication through the relevant DOI and the license). See: https://creativecommons.org/ licenses/by-nc-nd/4.0/.

\section{References}

1. National Academies of Sciences, Engineering, and Medicine. 2019. Crossing the Global Quality Chasm: Improving Health Care Worldwide. Washington, DC: The National Academies Press. Available online: https://doi.org/10.17226/25152

2. Nash DB. The Population Health Mandate: A broader approach to care delivery. BoardRoom Press (2012). February 2012. Available online: https://www.governanceinstitute.com/page/TGIBoardRoomPress

3. Kindig D, Stoddart G. What is population health? Am J Public Health 2003;93:380-3.

4. Remington PL, Catlin BB, Gennuso KP. The County Health Rankings: rationale and methods. Popul Health Metr 2015;13:11.

5. Whittington JW, Nolan K, Lewis N, et al. Pursuing the Triple Aim: The First 7 Years. Milbank Q 2015;93:263-300.

6. Provider-Led Population Health Management: Key Strategies for Healthcare in the Cognitive Era, 2nd Editions. (2016) Richard Hodach, Paul Grundy, Anil Jain, Michael Weiner, John Wiley \& Sons, Inc. Indianapolis IN 46256 2016. ISBN 9781119277231.

7. Bray F, Ferlay J, Soerjomataram I, et al. Global cancer statistics 2018: GLOBOCAN estimates of incidence and mortality worldwide for 36 cancers in 185 countries. CA Cancer J Clin 2018;68:394-424.

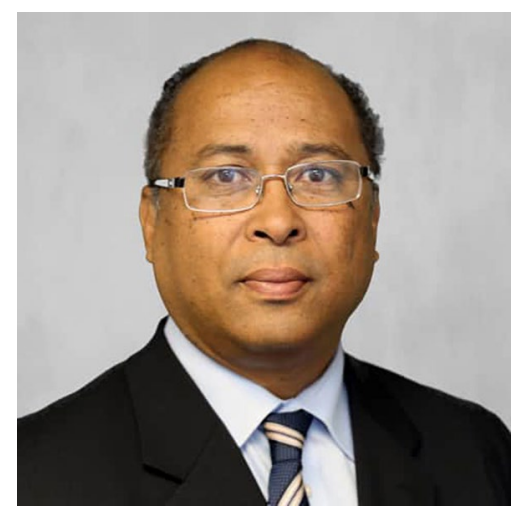

John F. Gibbs

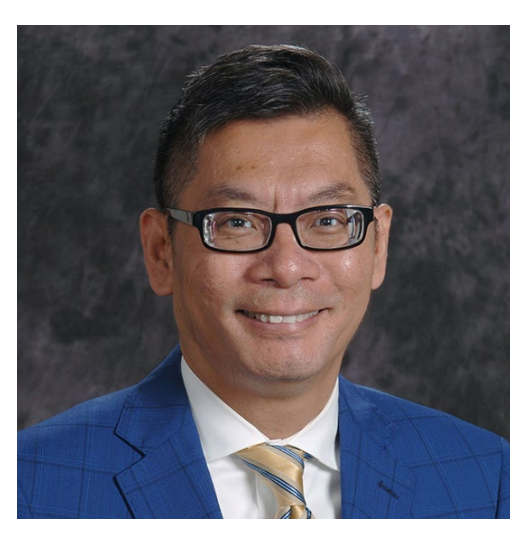

Quyen D. Chu

John F. Gibbs

Department of Surgery, Hackensack Meridian Health School of Medicine at Seton Hall University, Nutley, NF, USA.

(Email:Fobn.Gibbs@hmbn.org)

Quyen D. Chu

Department of Surgery, LSU-Shreveport School of Medicine, Shreveport, LA, USA.

(Email: QCbu@lsubsc.edu)

Submitted Oct 3, 2020. Accepted for publication Oct 14, 2020. doi: 10.21037/jgo-2019-gi-12

View this article at: http://dx.doi.org/10.21037/jgo-2019-gi-12

Cite this article as: Gibbs JF, Chu QD. Global GI malignancies: a population health management perspective. J Gastrointest Oncol 2021;12(Suppl 2):S273-S274. doi: 10.21037/jgo-2019-gi-12 